\title{
Records of scythridids (Lepidoptera: Scythrididae) from the southeastern Balkan
}

\author{
Kari Nupponen, Jari Junnilainen, Jari-Pekka Kaitila \& Timo Nupponen
}

Nupponen, K., Junnilainen, J., Kaitila, J.-P. \& Nupponen, T. 2007: Records of scythridids (Lepidoptera: Scythrididae) from the southeastern Balkan. — Entomol. Fennica 18: 1-10.

A list of 28 species embracing about 720 specimens of the family Scythrididae from the southeastern Balkan is presented. The material was collected from Bulgaria and northern Greece during 2000-2005. Scythris balcanica Jäckh, 1978 is synonimized with $S$. moldavicella Caradja, 1905, syn. n. The previously unknown females of Scythris ambustella Bengtsson, 1997, S. subaerariella (Stainton, 1867) and S. platypyga (Staudinger, 1880) are described. Seven species are reported as new for Bulgaria and four for Greece. Scythris lafauryi Passerin d'Entrèves, 1986 is reported for the first time from the Balkans. The known distribution range of each species is given.

Kari Nupponen, Miniatontie 1 B 9, FI-02360 Espoo, Finland; e-mail: Kari.Nupponen@Faunatica.fi

Jari Junnilainen, Mahlapolku 3, FI-01730 Vantaa, Finland

Jari-Pekka Kaitila, Kannuskuja 8 D 37, FI-01200 Vantaa, Finland

Timo Nupponen, Kartanonkuja 17 B 2, FI-02360 Espoo, Finland

Received 20 December 2005, accepted 31 January 2006

\section{Introduction}

The scythridid fauna of central and eastern parts of the Balkan region is generally rather poorly known. To date, 45 species of the family Scythrididae are known from that area, of which 38 from northern Greece and 27 from Bulgaria (see Bengtsson 1997). Only 20 species are in common for these countries, which may due to a low collecting activity in the area.

During 2000-2005, Finnish lepidopterists made seven expeditions to Bulgaria and northern Greece and collected a rather rich material of microlepidoptera, including numerous scythridids. The studies on Scythrididae revealed interesting results, including previously unknown females of three species, one new synonym, as well as seven species new for Bulgaria and four for Greece. The results of these studies and a list of all recorded scythridids are presented in this paper.

\section{The collecting sites, material and methods}

The investigated area is situated in southeastern part of the Balkan region: eastern and southern Bulgaria and northern Greece. The habitats were mainly open, xerothermic localities like hill slopes and different kinds of meadows.

The present article is based on the material collected during 2000-2005 in 7 different expeditions. The dates, visited areas and collectors on each of the trips are as follows: 


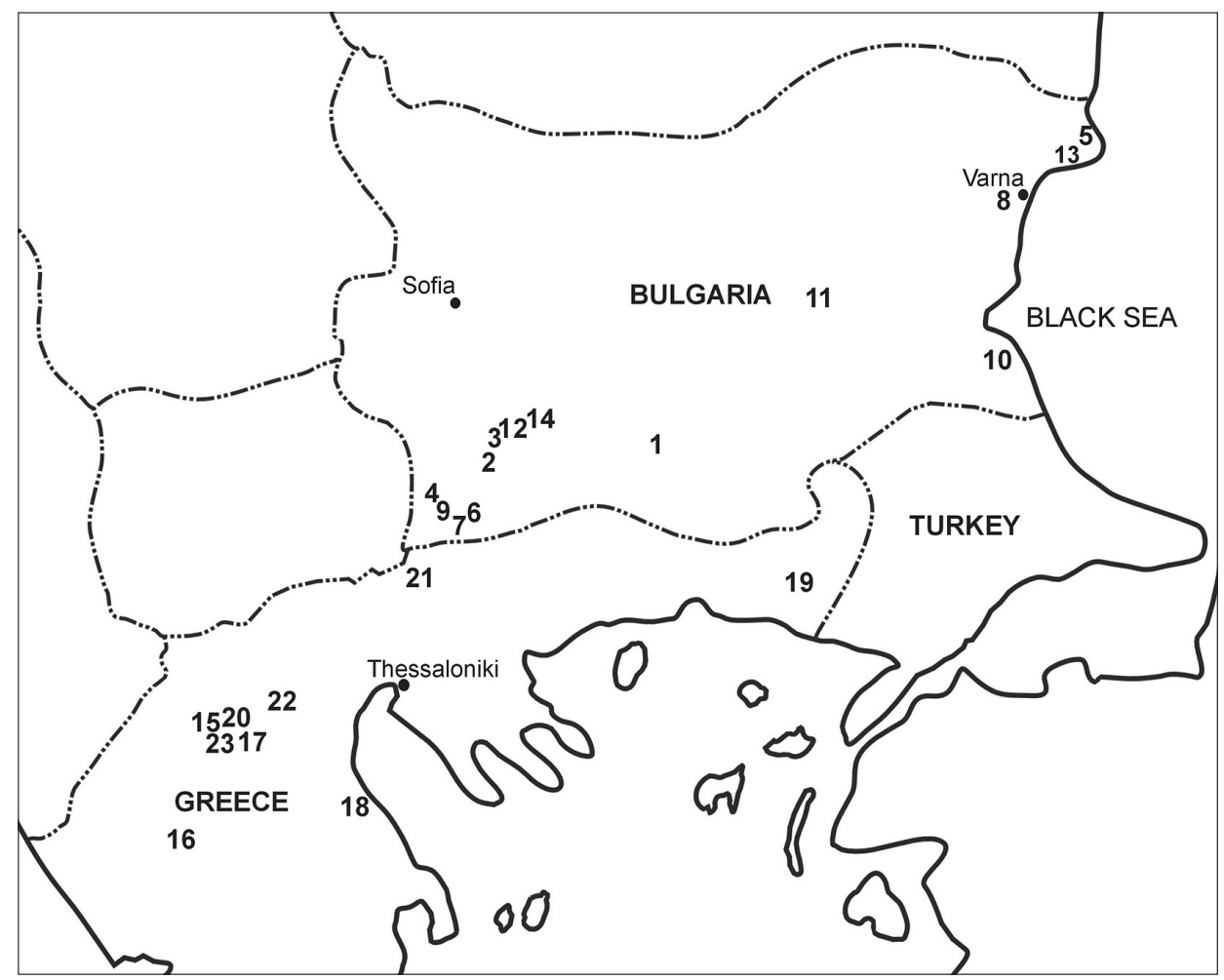

Fig. 1. Map of the southeastern Balkan region with collecting localities. -1 : BG, Asenovgrad. -2 : BG, Elesnica. - 3: BG, Jakoruda. - 4: BG, Kresna. - 5: BG, Nos Sabla. - 6: BG, Orelek. - 7: BG, Pirin. - 8: BG, Pobiti Kameni. - 9: BG, Popoti Livadi. - 10: BG, Ropotamo. - 11: BG, Sliven. - 12: BG, Sveta Petka. - 13: BG, Tuzlata. - 14: BG, Varvara. - 15: GR, Askio. - 16: GR, Grevena. - 17: GR, Kozani. - 18: GR, Leptokarya 1. - 19: GR, Leptokarya 2. - 20: GR, Metamorfosi. - 21: GR, Serres. - 22: GR, Vermio. - 23: GR, Xirolimni.

- 1: 18.-23.VI.2000; SW, C, E and NE Bulgaria; J. Junnilainen.

- 2: 21.-27.V.2001; NW Greece; J. Junnilainen.

- 3: 14.-27.VI.2001; SW, C, E and NE Bulgaria; J. Junnilainen, J-P. Kaitila.

- 4: 26.V.-09.VI.2002; SW, C, E and NE Bulgaria; J. Junnilainen, J-P. Kaitila.

- 5: 04.-10.VIII.2002; SW, C, E and NE Bulgaria; J. Junnilainen.

- 6: 18.-24.V.2003; NW Greece; J. Junnilainen, J-P. Kaitila.

- 7: 03.-07.VI.2005; NW and NE Greece; T. Nupponen.

The material, altogether about 720 specimens of scythridids, is deposited in the private collections of the observers. The overwhelming majority of the material was collected by sweeping and netting at daylight. A few specimens were also collected by artificial light at night. The material has been examined by Kari Nupponen and Jari Junnilainen. The collecting sites are shown in the map (Fig. 1).

The collecting localities are mentioned below. Brief variants of locality names are given in uppercase letters before each locality and used later in the species list. The number given to each of the localities is connected with that on the map (Fig. 1).

1, BG, ASENOVGRAD: S Bulgaria, $42^{\circ} 02^{\prime} \mathrm{N}$ 245'ㄹ, $210 \mathrm{~m}$, near Asenovgrad village. Calcareous, rocky slopes and a river valley with diversified low vegetation. 30.V.2002, 10.VIII.2002. 
2, BG, ELESNICA: SW Bulgaria, 41 ${ }^{\circ} 52^{\prime} \mathrm{N}$ $23^{\circ} 37^{\prime} \mathrm{E}, 800 \mathrm{~m}$, near Elesnica village. Meadows and sandy pasture for sheep with diversified low vegetation (Helianthemum, Thymus, Genista, etc.). 24.VI.2001.

3, BG, JAKORUDA: SW Bulgaria, $42^{\circ} 00^{\prime} \mathrm{N}$ $23^{\circ} 38^{\prime} \mathrm{E}, 930 \mathrm{~m}$, near Jakoruda village. Forest steppes between the mountains of Rila and Rodopi. 23.VI.2000, 25.VI.2001.

4, BG, KRESNA: SW Bulgaria, $41^{\circ} 43^{\prime} \mathrm{N}$ $23^{\circ} 09^{\prime} \mathrm{E}, 200 \mathrm{~m}$, near Kresna village. A river valley on foothills of the Pirin Mountains. A xerothermic locality with various kinds of dry meadows, railway banks, rocky and/or bushy slopes and ruderal places at roadside. 21.-22.VI.2000, 21.VI.2001, 06.-07.VIII. 2002.

5, BG, NOS SABLA: NE Bulgaria, $43^{\circ} 33^{\prime} \mathrm{N}$ $28^{\circ} 35^{\prime} \mathrm{E}, 0-10 \mathrm{~m}$, near Nos Sabla village. Sand dunes, moist meadows and wetlands near Black Sea shore close to Romanian border. 27.V.2002.

6, BG, ORELEK: SW Bulgaria, $41^{\circ} 33^{\prime} \mathrm{N}$ $23^{\circ} 37^{\prime} \mathrm{E}, 1,800 \mathrm{~m}$, southern part of Pirin Mountains, near Orelek village. Calcareous mountain tundra with luxurious low vegetation. 22.VI.2001, 08.VIII.2002.

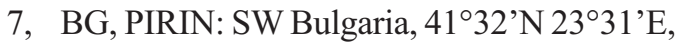
$760 \mathrm{~m}$, Pirin Mountains, near Pirin village. Dry meadows and bushy slopes. 21.24.VI.2001.

8, BG, POBITI KAMENI: NE Bulgaria, $43^{\circ} 12^{\prime} \mathrm{N} 27^{\circ} 40^{\prime} \mathrm{E}, 100 \mathrm{~m}$, Pobiti Kameni. A relict-like area of continental sand dunes. 30.V.2002, 04.VI.2002.

9, BG, POPOTI LIVADI: SW Bulgaria, $41^{\circ} 37^{\prime} \mathrm{N} \quad 23^{\circ} 19^{\prime} \mathrm{E}, \quad 900-1,300 \mathrm{~m}$, Pirin Mountains, near Popoti Livadi village. Deciduous forests (Ulmus) and bushy meadows. 21.-24.VI.2001.

10, BG, ROPOTAMO: SE Bulgaria, $42^{\circ} 19^{\prime} \mathrm{N}$ 274' E, 10-20 m, Burgas $40 \mathrm{~km} \mathrm{SE}$, Ropotamo. A mosaic of coastal sand dunes, old deciduous forests (Quercus, Ulmus, Fraxinus), meadows, moist patches and wetlands. 16.-20.VI.2001, 05.-07.VI.2002.

11, BG, SLIVEN: C Bulgaria, $42^{\circ} 41^{\prime} \mathrm{N} 26^{\circ} 22^{\prime} \mathrm{E}$, $300 \mathrm{~m}$, southern slope of Slivenska Planina. Rocky slopes and deciduous forests (Quercus, Ulmus). 18.-19.VI.2000, 23.VI. 2000,
25.VI.2001，02.-03.VI.2002，04.-05.VIII. 2002, 10.VIII.2002.

12, BG, SVETA PETKA: SW Bulgaria, $42^{\circ} 02^{\prime} \mathrm{N}$ 240'ㄹ, $800 \mathrm{~m}$, near Sveta Petka village. Grassy forest steppe slopes with diversified low vegetation (Helianthemum, Thymus, Genista, etc.). 31.V.2002, 09.VIII.2002.

13, BG, TUZLATA: NE Bulgaria, 4312’N $27^{\circ} 57^{\prime} \mathrm{E}, 5-30 \mathrm{~m}$, near Tuzlata village. Chalk hills close to Black Sea shore with diversified low vegetation. 14.-16.VI.2001, 26.-27.VI. 2001，26.V.2002，28.V.2002，05.VI.2002, 08.-09.VI.2002, 10.VIII.2002.

14, BG, VARVARA: SW Bulgaria, $42^{\circ} 08^{\prime} \mathrm{N}$ $24^{\circ} 07^{\prime} \mathrm{E}, 480 \mathrm{~m}$, near Varvara village. A river valley with steep slopes and diversified low vegetation. 31.V.2002, 06.VIII.2002.

15, GR, ASKIO: NW Greece, prov. Makedonia, Kozani NW, 40²2’N 2130’E, $1450 \mathrm{~m}$, Askio Mountains. Open, grassy meadows and rocky patches. 23.V.2003.

16, GR, GREVENA: NW Greece, prov. Make-

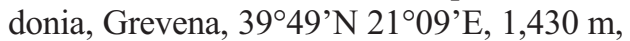
Grevena town $35 \mathrm{~km} \mathrm{~S}$. A hill area with oak forests and dry meadows. 24.V.2001.

17, GR, KOZANI: NW Greece, prov. Makedonia, Kozani, $40^{\circ} 13^{\prime} \mathrm{N} 21^{\circ} 49^{\prime} \mathrm{E}, 480 \mathrm{~m}$, near Kozani town. Open, xerothermic slopes with diversified low vegetation (Thymus, Astragalus, Helianthemum, Aster, Silene, etc.). 23.-24.V.2003.

18, GR, LEPTOKARYA 1: NW Greece, prov. Makedonia, Pieriá, $40^{\circ} 01^{\prime} \mathrm{N} 22^{\circ} 29^{\prime} \mathrm{E}, 750 \mathrm{~m}$, Leptokarya village near Mount Olympos. Different kinds of meadows and bushy slopes with interesting vegetation (Ilex, Abies, Thymus, Scleranthus, Helianthemum, Viola, etc.). 21.-23.V.2001, 27.V.2001.

19, GR, LEPTOKARYA 2: NE Greece, prov. Thraki, Evros, $41^{\circ} 01^{\prime} \mathrm{N} 26^{\circ} 03^{\prime} \mathrm{E}, 370 \mathrm{~m}$, near Leptokarya village. Deciduous forests, xerothermic open slopes and meadows. 05.07.VI.2005.

20, GR, METAMORFOSI: NW Greece, prov. Makedonia, Kozani, 40²2’N 2143’E, 990 $\mathrm{m}$, Kozani town NW, near Metamorfosi village. Rocky steppe slopes with interesting low vegetation (Thymus, Scleranthus, Stipa, Eryngium, Helianthemum, etc.). 22.V.2003.

21, GR, SERRES: N Greece, prov. Makedonia, 
Serres, $41^{\circ} 16^{\prime} \mathrm{N} 23^{\circ} 04^{\prime} \mathrm{E}, 140 \mathrm{~m}$, Serres town $41 \mathrm{~km} \mathrm{~W}$, Promahonas. Roadside meadows, railway banks, rocky and bushy slopes close to Bulgarian border. 25.-26.V.2001.

22, GR, VERMIO: NW Greece, prov. Makedonia, Imathia, $40^{\circ} 29^{\prime} \mathrm{N} 22^{\circ} 03^{\prime} \mathrm{E}, 1350 \mathrm{~m}$, Kozani town NE, Vermio Mountains. Bushy meadows and pasture grounds. 22.V.2003.

23, GR, XIROLIMNI: NW Greece, prov. Makedonia, Kozani, $40^{\circ} 18^{\prime} \mathrm{N} 21^{\circ} 35^{\prime} \mathrm{E}, 1,000 \mathrm{~m}$, near Xirolimni village. Rocky steppe slopes with diversified low vegetation (Thymus, Scleranthus, Stipa, Eryngium, Helianthemum, Dianthus, Artemisia, etc.). 21.-23.V. 2003, 04.-05.VI.2005.

\section{List of scythridid species}

The species are presented in a putative, natural sequence introduced in the recent review of the Scythrididae of Europe s. 1. (Bengtsson 1997). The known distribution for each species is given, based on data by Bengtsson (1997) and Fauna Europaea (2005). The observer of each record is mentioned in square brackets as follows: $[\mathrm{JJ}]=\mathrm{J}$. Junnilainen, $[\mathrm{JPK}]=\mathrm{J}$-P. Kaitila, $[\mathrm{TN}]=\mathrm{T}$. Nupponen.

Scythris cuspidella (Denis \& Schiffermüller, 1775)

BG, Sliven, 18.-19.VI.2000 common, [JJ]

BG, Jakoruda, 25.VI.2001 common, [JJ]

BG, Pirin, 21.-24.VI.2001 common, [JJ] [JJ]

BG, Ropotamo, 26.-27.VI.2001 common,

Distribution. C and S Europe, Russia (Chita region, Yakutia, Amur).

Scythris flavilaterella (Fuchs, 1886)

BG, Sliven, 18.-19.VI.2000 2 ઈิ 1 오, [JJ]

Distribution. C and S Europe, Caucasus, Russia (S Ural).

Remarks. New to Bulgaria.

Scythris obscurella (Scopoli, 1763) $[\mathrm{JJ}]$

BG, Popoti Livadi, 21.-24.VI.2001 1 §ै 1 ㅇ,

BG, Ropotamo, 26.-27.VI.2001 1 ๙े, [JJ]

GR, Leptokarya 1, 21.-23.V.2001 1 \%, [JJ]
Distribution. C and S Europe, Baltic countries and Finland eastwards to S Siberia (Baikal region).

Scythris moldavicella Caradja, 1905

Scythris balcanica Jäckh, 1978 Syn. n.

Scythris ottomana Jäckh, 1978

BG, Pobiti Kameni, 30.V.2002 25 ํํ 2 오오, [JJ]; 04.VI.2002 1 ふ,, [JPK]

BG, Kresna, 31.V.-02.VI.2002 7 ふぇ, [JJ]; 9

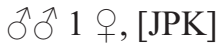

BG, Tuzlata, 05.VI.2002 and 08.-09.VI.2002 2 ठ઼ 1 ,,$[\mathrm{JJ}]$

BG, Pirin, 21.-24.VI.2001 1 ठे, [JJ]

GR, Grevena, 24.V.2001 2 ๙ै के 1 ㅇ, [JJ]

GR, Xirolimni, 04.VI.2005 1 ठे, [TN]

Genitalia slide: K. Nupponen prep. no. 2/15. II.2005 (†); three genitalia preparations (ふぶ) preserved in glycerol.

Distribution. Bulgaria, Romania, Albania, former Yugoslavia, Greece, Turkey. The species is reported also from Portugal (Bengtsson 1991, Fauna Europaea 2005), but according to Bengtsson (1997) the records from there are incorrect.

Remarks. S. balcanica is a poorly known species and its status has been confusing, because only a few females were available and a male re-

Fig. 2. Female genitalia of Scythris moldavicella Caradja, 1905

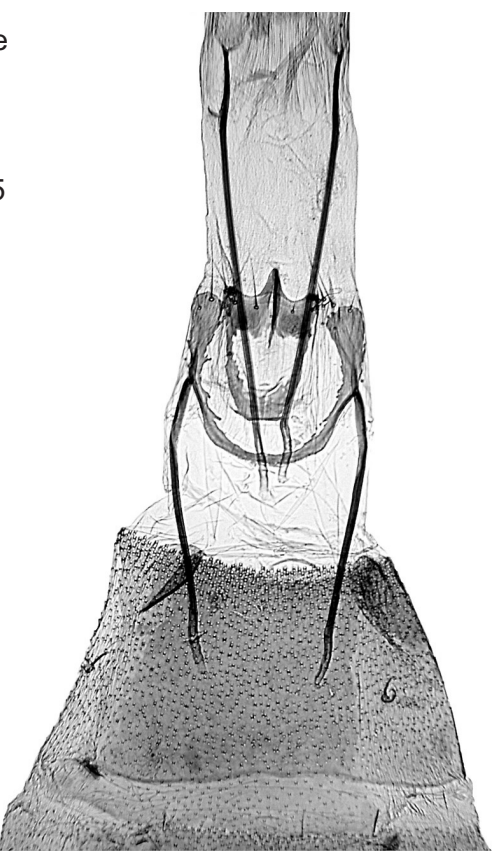


mained unknown. Furthermore, the superficially similar S. moldavicella is widespread in the same region where balcanica occurs, but the female of moldavicella has never been described. The present material, including a series of both males and females from several localities in Bulgaria, allows to study the external variation of $S$. moldavicella, as well as genitalia of both sexes. In three localities, males and females were observed simultaneously and there is no doubt that they belong to the same taxon. The male genitalia equal to those of $S$. moldavicella (holotype) illustrated by Bengtsson (1997), and the female genitalia exactly coincide with those of the holotype of $S$. balcanica (see Bengtsson 1997) (Fig. 2). Thus, $S$. balcanica is a junior synonym of $S$. moldavicella.

$S$. moldavicella is externally a variable species. Especially a white streak in fold of the forewing is variable. In some specimens it is broad, distinct and fused to a dash above tornus, and sometimes subapical and apical spots of same colour are present. On the other hand, in some cases the streak is reduced to a few pale scales in fold from base to midwing. The external appearance of female equals to that of male, excluding the abdomen. The abdomen of female is fuscous, ventrally with scattered dirty whitish scales occurring more densely laterally and almost covering ventral segments VI-VII. In the female genitalia, sternum VII is subrectangular with slightly concave posterior margin and a rather membranous, oval medioposterior process.

Scythris potentillella (Zeller, 1847)

BG, Kresna, 21.-22.VI.2000 1 ふे, [JJ]

Distribution. Europe, Asia Minor.

Remarks. New to Bulgaria.

Scythris limbella (Fabricius, 1775)

BG, Pirin, 21.-24.VI.2001 1 9, [JJ]

BG, Sliven, 05.VIII.2002 1 ex., [JJ]

Distribution. W Palaearctic, E Nearctic.

Scythris ambustella Bengtsson, 1997

GR, Xirolimni, 21.-23.V.2003 3 ठึ 1 ㅇ, [JJ]; Genitalia slide: K. Nupponen prep. no. 2/12.IV.2004 (q); one genitalia preparation (ठ) preserved in glycerol.

GR, Metamorfosi, 22.V.2003 1 §ै, [JPK]

Distribution. Greece.
Remarks. S. ambustella is previously known by the holotype (male) only. Bengtsson (1997) provisionally placed the taxon in the knochella species-group. There are some details in the female genitalia of $S$. ambustella that do not exist in European species of the group, like a sclerotized antrum and a medioposterior process in sternum VII. However, those characteristics are present in three Central Palaearctic species $(S$. elenae K. Nupponen, 2000, S. hamardabanica K. Nupponen, 2003 and S. juerivetei K. Nupponen, 2005; see Nupponen et. al. 2000, 2005, Nupponen 2003,2005 ), which supposed to be related to either cicadella or knochella species-groups. The latter character also exists in S. moldavicella Caradja, 1905 (see below) belonging to the cicadella-group. Thus, S. ambustella probably belongs to the knochella-group as Bengtsson (1997) presumed, but the diagnostic characters of the cicadella and knochella species-groups overlap (see Nupponen 2003).

Externally the female of $S$. ambustella is similar to the male, but somewhat smaller in size (wingspan $11.5 \mathrm{~mm} ; 12-13 \mathrm{~mm}$ in male) and hindwings are yellowish brown (blackish brown in male) (Fig. 3). The abdomen of female is dor-

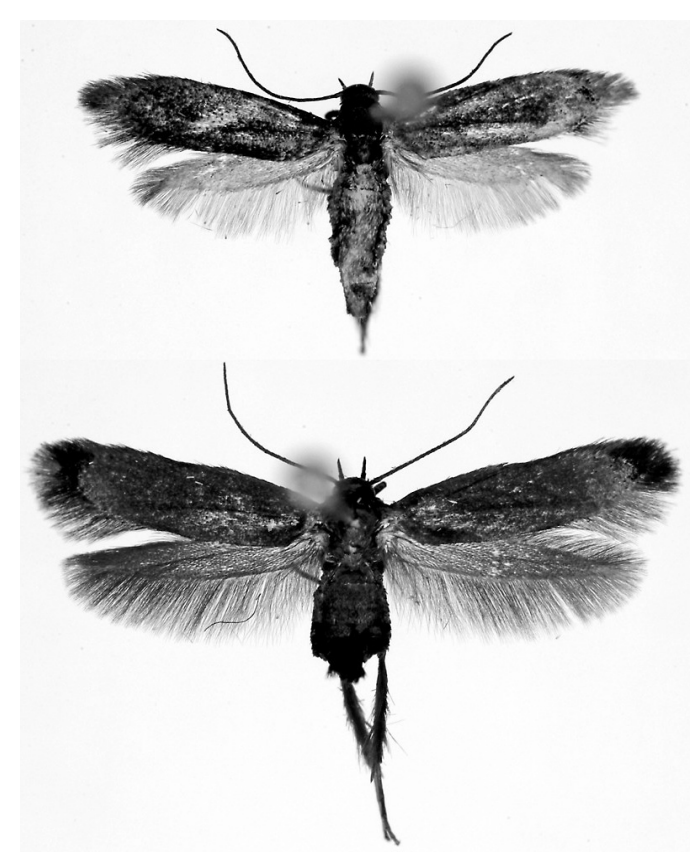

Fig. 3. Female (up) and male (down) of Scythris ambustella Bengtsson, 1997. 


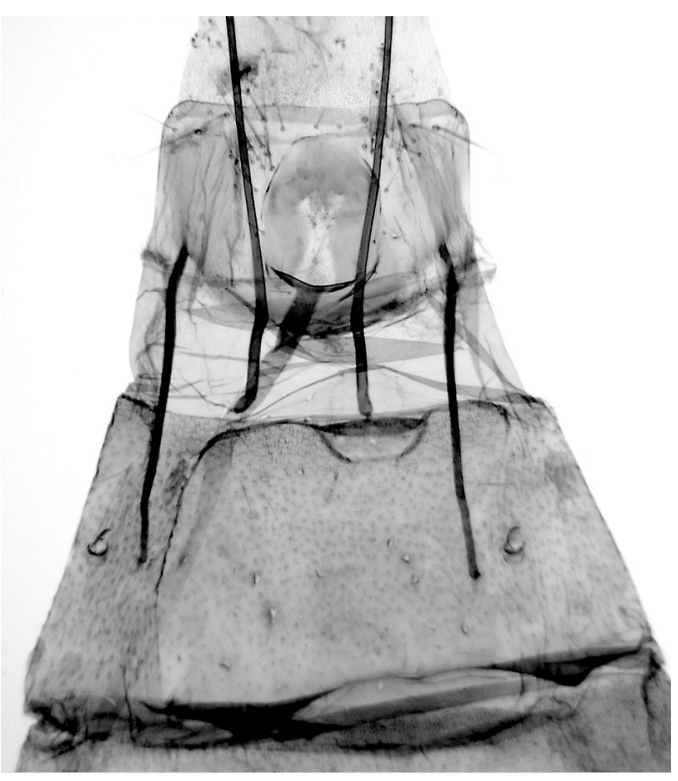

Fig. 4. Female genitalia of Scythris ambustella (prep. no. 2/12.IV.2004 KN).

sally fuscous, more or less densely covered by rusty brown scales; ventrally fuscous except segments VI and VII that are pale yellowish brown.

Description of female genitalia (Fig. 4). Sterigma oval, medially membranous. Antrum sclerotized, distally wide. Sternum VII subrectangular, medioposteriorly incised and with a flattened structure; anterior margin medially concave, with small bulges near corners. Apophyses anteriores $0.55 \times$ length of apophyses posteriores.

Scythris flabella (Mann, 1861)

BG, Kresna, 21.-22.VI.2000 common, [JJ], 22.VI.2001 1 ๙, [JPK]

Distribution. Bulgaria, former Yugoslavia, Moldova, Ukraine, Turkey, Armenia, Iran.

Scythris albostriata Hannemann, 1961

GR, Serres, 25.-26.V.2001 1 ex, [JJ]

Distribution. Albania, Greece, Romania, former Yugoslavia.

Scythris confluens (Staudinger, 1871)

GR, Xirolimni, 21.-23.V.2003 1 §ึ 2 우, [JJ]

GR, Kozani, 23.-24.V.2003 1 § 2 우, [JJ]

GR, Xirolimni, 04.VI.2005 1 ๙ึ 2 우, [TN]

Distribution. Greece, Makedonia.
Scythris pudorinella (Möschler, 1866)

GR, Kozani, 23.-24.V.2003 3 ふ઼ , [JJ]

Distribution. Bulgaria, Greece, Romania, Moldova, Ukraine, Belarus, Russia (S Ural, lower Volga region, Altai Mnts), Turkey.

Scythris subaerariella (Stainton, 1867)

BG, Pobiti Kameni, 04.VI.2002 several exx., [JJ]; 5 exx., [JPK]

BG, Tuzlata, 05.VI.2002 1 ex., 27.-28.VI. 20011 ex., [JPK]

GR, Xirolimni, 21.-23.V.2003 1 q, [JJ]; 04.VI.2005 1 ठ̊, [TN]; Genitalia slide: K. Nupponen prep. no. 3/12.IV.2004 (q).

Distribution. Romania, Bulgaria, Greece, Turkey, Russia (S Ural).

Remarks. Although S. subaerariella is widely distributed and locally rather common in southeastern Europe and Turkey, the external appearance and genitalia of the female have never been described. The external appearance and size of the female (wingspan $13 \mathrm{~mm}$ ) is similar to that of the male, excluding underside of hindwings and the abdomen. The underside of hindwing is fuscous in both sexes, but in female the basal half is densely covered by dark brown scales. The abdomen of female is fuscous; rusty brown scales

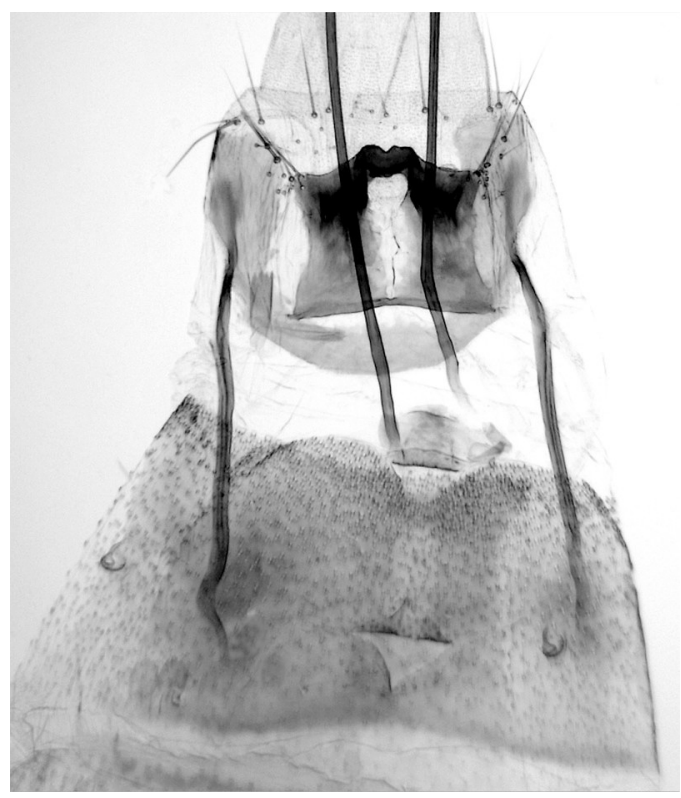

Fig. 5. Female genitalia of Scythris subaerariella (Stainton, 1867) (prep. no. 3/12.IV.2004 KN). 
dorsally at segments I-IV; ventrally with scattered white scales, anal tuft pale yellowish white. Our specimens from Greece and Bulgaria are less mottled than specimens from Turkey and S Ural, as pale brown scales on the forewings are scarce or even absent.

Description of female genitalia (Fig. 5). Sterigma subquadrangular, median part membranous; anterior margin straight and strongly sclerotized; lateral margins concave; posterior corners bristled; posterior margin extended, medially with a more sclerotized, medioposteriorly incised structure fused to sterigma. Sternum VII subrectangular, posterior corners rounded; posterior margin medially incised and with a subtrapezoid process. Apophyses anteriores $0.6 \times$ length of apophyses posteriores.

\section{Scythris clavella (Zeller, 1855)}

BG, common and widely distributed: Kresna, Ropotamo, Sliven, Sveta Petka, Tuzlata, Varvara, [JJ]

GR, Kozani 23.-24.V.2003, common, [JJ]

Distribution. C and S Europe eastwards to the southern Ural Mountains; Altai Mountains. Recently reported from Central Asia (Kazakhstan, Kirgisia; K. Nupponen et. al. 2005).

Remarks. New to Bulgaria and Greece.

Scythris seliniella (Zeller, 1839)

BG, Varvara, 31.V.2002 2 ठิ่, [JJ]

BG, Kresna, 21.-22.VI.2000 1 क [JJ]; 31.V.02.VI.2002 3 exx., [JPK]

BG, Orelek, 22.VI.2001 2 exx., [JPK]

BG, Tuzlata, 26.V.2002 1 ex., 05.VI.2002 3 exx., [JPK]

BG, Asenovgrad, 20.VI.2000 1 ex., [JJ]

GR, Leptokarya 1, 18.-21.V.2003 2 exx., [JPK]

GR, Vermio, 18.V.2003 9 exx., [JPK]

GR, Askio, 23.V.2003 2 exx., [JPK]

GR, Kozani, 23.-24.V.2003 2 exx., [JJ]

GR, Xirolimni, 21.-23.V.2003 5 exx., [JPK]; 04.VI.2005 2 ふぇ, 05.VI.2005 1 Љ 2 우, [TN]

GR, Leptokarya 2, 05.VI.2005 2 ๙ิำ 2 우우,

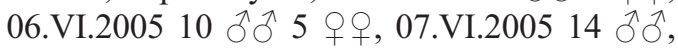
[TN]

Distribution. C and S Europe, Asia Minor.
Scythris anomaloptera (Staudinger, 1880)

BG, Jakoruda, 25.VI.2001 1 స, [JJ]

BG, Tuzlata, 14.-16.VI.2001 2 ๙े 1 ㅇ, [JJ], 16.VI.2001 1 ふૈ, 26.V.2002 4 ふぇ,, [JPK]

GR, Leptokarya 2, 06.VI.2005 1 § 1 ㅇ, [TN]

Distribution. Spain, France, Yugoslavia, Turkey. Recently recorded from S Russia, lower Volga region (Volgograd distr., Olhovka village 20 km S, 13 exx. 15.V.2005, K. Nupponen leg.).

Remarks. New to Bulgaria, Greece and Russia.

Scythris hungaricella Rebel, 1917

BG, Asenovgrad, 20.VI.2000 1 ठ, [JJ]

BG, Ropotamo, 16.-20.VI.2001 common, [JJ]

BG, Tuzlata, 27.-28.VI.2001 common, [JJ]; 05.VI.2002 2 ふึ ๙, [JPK]

Distribution. Slovakia, Hungary, Romania, Bulgaria, Croatia, former Yugoslavia, Greece, Syria.

Scythris tergestinella (Zeller, 1855)

BG, Tuzlata, 14.-16.VI.2001 and 05.VI.2002 common, [JJ]

GR, Leptokarya 1, 21.-23.V.2001 several exx., [JJ]

GR, Leptokarya 2, 06.VI.2005 1 ふ, [TN]

Distribution. Southern C and S Europe.

Scythris platypyga (Staudinger, 1880)

BG, Tuzlata, 14.-16.VI.2001 2 exx., 05.VI.2002 3 exx., 08.-09.VI.2002 1 ex., [JJ]; 26.V.2001 5 ふぇう, [JPK]

GR, Xirolimni, 21.-23.V.2003 3 오, [JJ]; Genitalia slide: K. Nupponen prep. no. 1/15.II. 2005 ( 9 ).

GR, Kozani, 23.-24.V.2003 1 ふै, [JJ]

Distribution. Bulgaria, Turkey.

Remarks. New to Greece. Although $S$. platypyga is rather widespread in Turkey and southern Balkans, the female remained unknown to date. Externally the female is similar to the male, except the abdomen. In ventral side of the female abdomen, the 7 th segment is pale beige and same coloured scattered scales exist in terminal part of the abdomen.

Description of female genitalia (Fig. 6). Sterigma large, subtriangular; anterior corners rounded and slightly extended; anterior margin 


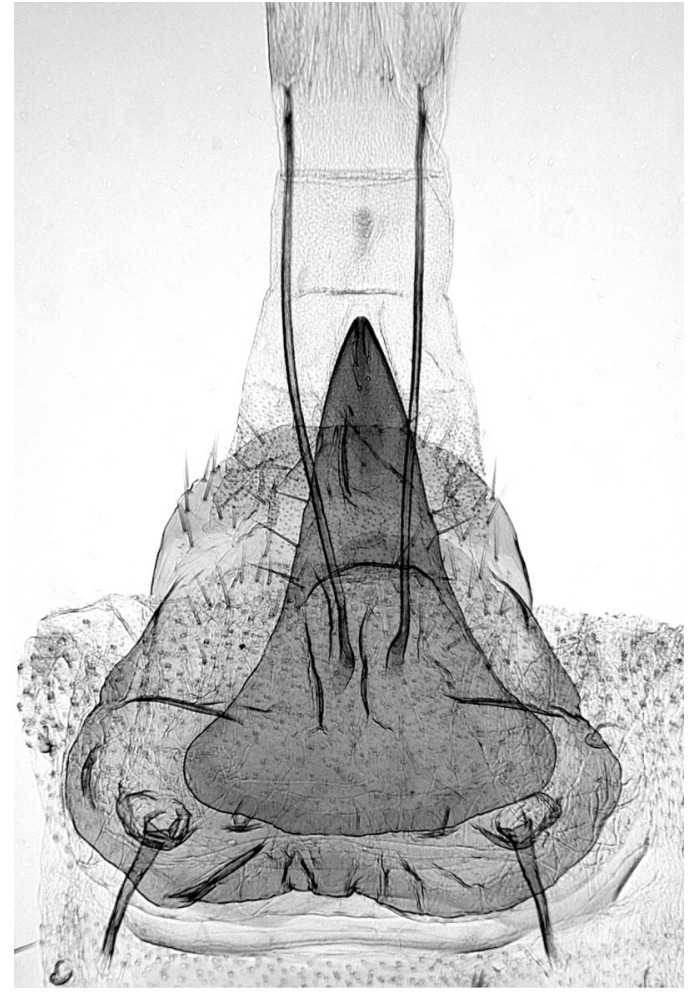

Fig. 6. Female genitalia of Scythris platypyga (Staudinger, 1880) (prep. no. 1/15.II.2005 KN).

convex. Sternum VIII subrectangular, membranous. Dorsad segment VIII a large, sclerotized, subtrapezoid plate. Apophyses anteriores $0.2 \times$ length of apophyses posteriores.

Scythris inertella (Zeller, 1855)

BG, Tuzlata, 14.-16.VI.2001 common, [JJ]

Distribution. S Europe, Ukraine, Belarus, Caucasus, N Africa, Asia Minor, Middle East.

Scythris picaepennis (Haworth, 1828)

BG, Pirin, 21.-24.VI.2001 2 exx., [JJ]

BG, Jakoruda, 23.VI.2000 several exx., [JJ]

GR, Serres, 25.-26.V.2001 1 ex., [JJ]

Distribution. C and S Europe, S Scandinavia,

Estonia, Caucasus, Japan.

Scythris eberhardi Bengtsson, 1997

GR, Serres, 25.-26.V.2001 2 ふे, [JJ]

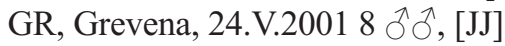

GR, Xirolimni, 21.-23.V.2003 1 ठิ, [JJ];

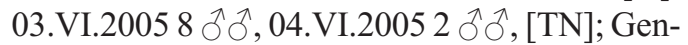

italia slide: K. Nupponen prep. no. 3/08.IV.2004.

Distribution. Greece.

Remarks. S. eberhardi is previously known by two males from southern Greece (see Bengtsson 1997). However, the taxon appears to be rather widely distributed in Greece and locally it is not rare in northwestern part of the country. The moth occurs in xerothermic, rocky slopes. The main flight period is late May.

Scythris tributella (Zeller, 1847)

BG, Tuzlata, 05.VI.2002 common, [JJ], 16.VI.2001 1 , [JPK]

BG, Nos Sabla, 27.V.2002 1 ふ, [JPK], 1 ○ 3 우, [JJ] [JJ]

BG, Ropotamo, 05.-07.VI.2002 several exx., [JJ]

GR, Leptokarya 1, 25.VII.2001 several exx.,

GR, Grevena, 24.V.2001 several exx., [JJ]

GR, Xirolimni, 21.-23.V.2003 2 exx., [JJ]

Distribution. C and S Europe, Libya, Russia (S Ural).

Remarks. New to Bulgaria. Records of S. tributella from Estonia (Teich 1899, Luig \& Kesküla 1995, Fauna Europaea 2005) are based on misidentification. The species was recently omitted from the Estonian list (Jürivete et. al. 2000).

Scythris lafauryi Passerin d'Entrèves, 1986

BG, Kresna, 21.-22.VI.2000 4 ふふ, 1 , [JJ]. Genitalia slide: K. Nupponen prep. no. 1/12.IV. 2004 (Figs. 7-8).

GR, Leptokarya 2, 06.VI.2005 12 ठぇ 7 우, 07.VI.2005 10 Љ ठ 1 ㅇ, [TN]

Distribution. Spain, France.

Remarks. The species is previously known only from southwestern Europe. Compared to Spanish specimens, the pattern of the forewings are more distinct in specimens from Balkans (Fig. 9). However, there is no regional variation in the genitalia. The present records extend the known distribution range of the taxon considerably to the east. The habitats both in Bulgaria and in Greece are xerothermic gravel pits. New to Bulgaria and Greece. 


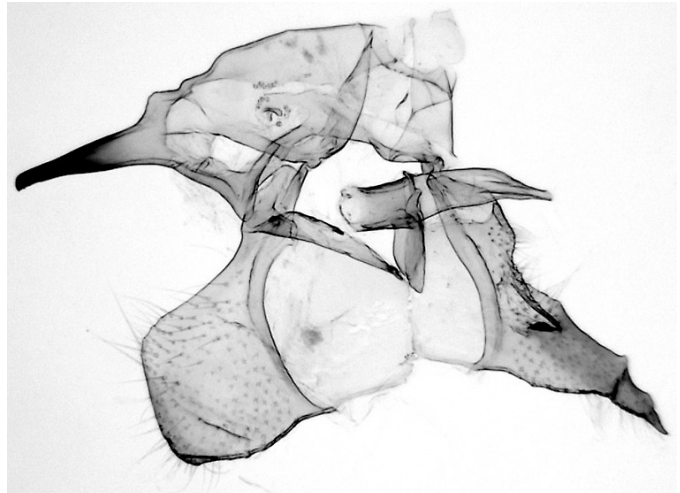

Fig. 7. Male genitalia of Scythris lafauryi Passerin d'Entrèves, 1986 (prep. no. 1/12.IV.2004 KN).

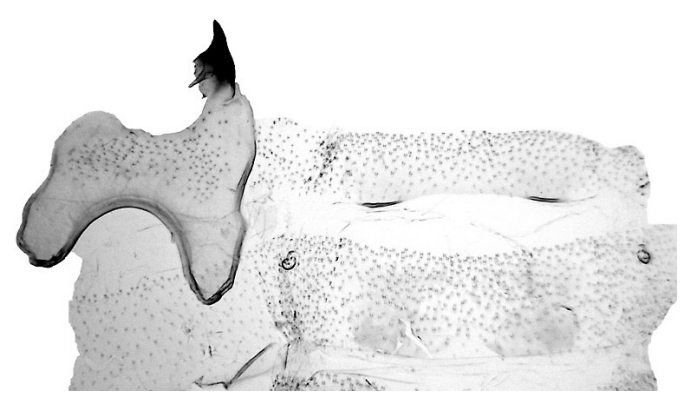

Fig. 8. Tergum VIII (left) and sternum VIII (right) of Scythris lafauryi (prep. no. 1/12.IV.2004 KN).

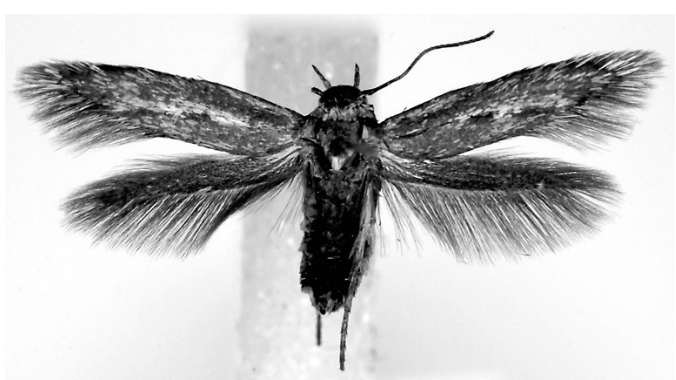

Fig. 9. Imago (male) of Scythris lafauryi from Bulgaria.

Scythris crypta Hannemann, 1961

BG, Elesnica, 24.VI.2001 1 $\hat{\sigma},[\mathrm{JJ}]$; Genitalia slide: K. Nupponen prep. no. 4/12.IV.2004.

Distribution. Bulgaria, Czech Republic, Denmark, Greece, Italy, former Yugoslavia, Sweden, Turkey.
Scythris gravatella (Zeller, 1847)

BG, Tuzlata, 14.-16.VI.2001 common, [JJ], 15.-16.VI.2001 10 exx., 27.-28.VI.2001 1 ex., 26.V.2003 2 exx., 05.V.2002 2 exx., [JPK]

BG, Sveta Petka, 31.V.2002 several exx., [JJ]

GR, Serres, 25.-26.V.2001 several exx., [JJ]

GR, Metamorfosi, 22.V.2003 1 त, [JPK]

GR, Xirolimni, 21.-23.V.2003 5 exx., [JPK]

GR, Kozani, 23.-24.V.2003 1 ๙े, [JJ]

GR, Leptokarya 2, 05.VI.2005 1 §, 06.VI.

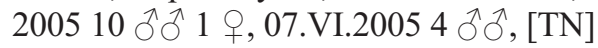

Distribution. S Europe, Tunisia.

Scythris tabidella (Herrich-Schäffer, 1855)

BG, Sliven, 18.-19.VI.2000 common, [JJ],

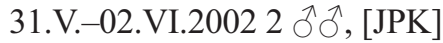

BG, Kresna, 21.-22.VI.2000 common, [JJ]

BG, Pirin, 21.-24.VI.2001 common, [JJ]

Distribution. C and S Europe, C Asia.

Remarks. New to Bulgaria.

Scythris fallacella (Schläger, 1847)

BG, Jakoruda, 23.VI.2000 several exx., [JJ]

Distribution. S and C Europe, Turkey. Reported also from the eastern part of European Russia (Fauna Europaea 2005).

Episcythris triangulella (Ragonot, 1875)

BG, Sliven, 23.VI.2000 1 ठे, [JJ]

Distribution. Morocco, Portugal, Corsica, Sardinia, Sicily, Greece, Bulgaria, Romania.

Acknowledgements. We thank Kimmo Silvonen (Espoo, Finland) and Finnish Museum of Natural History, University of Helsinki for their help in processing the photographs, as well as Urmas Jürivete (Tallinn, Estonia), Ole Karsholt (Copenhagen, Denmark) and an anonymous referee for useful comments on the manuscript, and Faunatica Oy for supporting this work.

\section{References}

Bengtsson, B. A. 1991: Contribution to the knowledge of the scythridid fauna of SW Europe (Lepidoptera: Scythrididae). - SHILAP Revta Lepid. 19: 35-51.

Bengtsson, B. Å. 1997: Scythrididae. — In: Huemer, P., Karsholt, O. \& Lyneborg, L. (eds.), Microlepidoptera of Europe 2: 1-301.

Fauna Europaea 2005: Fauna Europaea. - [www document]. URL www.faunaeur.org.

Jürivete, U., Kaitila, J., Kesküla, T., Nupponen, K., Viida- 
lepp, J. \& Öunap, E. 2000: Eesti Liblikad, Kataloog. Estonian Lepidoptera, Catalogue. - Tallinn. 151 pp. Luig, J. \& Kesküla, T. 1995: Catalogus Lepidopterorum Estoniae. - Tartu. 130 pp.

Nupponen, K. 2003: Contribution to the scythridid fauna of southern Buryatia, with description of seven new species (Lepidoptera: Scythrididae). — Entomologica Fennica 14(1): 25-45.

Nupponen, K., Jürivete, U. \& Pototski, A. 2005: Records of scythridids from Southeastern Kazakhstan, with description of five new species (Lepidoptera: Scythrididae). - Entomologica Fennica 16(2): 65-73.

Nupponen, K. 2005: Notes on Palaearctic Scythrididae, with description of two new species (Lepidoptera: Scythrididae). — Entomologica Fennica 16(3): 165174.

Nupponen, K., Bengtsson, B. Å., Kaitila, J.-P., Nupponen, T., Junnilainen, J. \& Olschwang, V. 2000: The scythridid fauna of the southern Ural Mountains, with description of fourteen new species (Lepidoptera: Scythrididae). - Entomologica Fennica 11(1): 5-34.

Teich, C. A. 1899: Vervollständigtes Verzeichnis der Schmetterlinge der baltischen Provinzen, soweit sie bis zum Frühjahres des Jahres 1899 bekannt geworden sind. - Korrespondenzblatt des NaturforscherVereins zu Riga 42: 9-76. 